\title{
The importance of specialization training and opportunities to utilize the qualifications of specialists in long-term care nursing to improve the quality of nursing care of chronically and terminally ill patients
}

\author{
Znaczenie szkolenia specjalizacyjnego i możliwości wykorzystania kwalifikacji specjalistów \\ w dziedzinie pielęgniarstwa opieki długoterminowej w zakresie poprawy jakości opieki \\ pielęgniarskiej nad przewlekle i nieuleczalnie chorymi
}

\section{Ewa Kądalska, Halina Żmuda-Trzebiatowska, Katarzyna Pawłowska}

Zakład Pielęgniarstwa Klinicznego, Wydział Nauki o Zdrowiu, Warszawski Uniwersytet Medyczny/ Clinical Nursing Department, Faculty of Health Sciences, Medical University of Warsaw

CORRESPONDING AUTHOR/AUTOR DO KORESPONDENCJ:

Ewa Kądalska

Zakład Pielęgniarstwa Klinicznego Wydział Nauki o Zdrowiu

Warszawski Uniwersytet Medyczny ul. Ciołka 27, 01-445 Warszawa e-mail: ekadalska@wp.pl

STRESZCZENIE

Słowa kluczowe:

ABSTRACT

Key words:
WYKORZYSTANIE KWALIFIKACJI SPECJALISTÓW W DZIEDZINIE PIELĘGNIARSTWA OPIEKI DLUGOTERMINOWEJ W ZAKRESIE POPRAWY JAKOŚCI OPIEKI PIELEGNIARSKIEJ NAD PRZEWLEKLE I NIEULECAALNIE CHORYMI

Cel pracy. Analiza przydatności szkolenia specjalizacyjnego w dziedzinie pielęgniarstwa opieki długoterminowej oraz możliwości wykorzystania zdobytych kwalifikacji - w opinii specjalistów w tej dziedzinie.

Materiał i metodyka. W badaniu ankietowym wzięło udział 162 specjalistów w dziedzinie pielęgniarstwa opieki długoterminowej. Wyniki badań. Większość badanych uznała szkolenie specjalizacyjne za przydatne $(91,4 \%)$ oraz spełniające ich oczekiwania $(83,9 \%)$. W wyniku ukończonej specjalizacji lepiej wykonują oni własną pracę przy chorym (67,9\%), wykazują się fachowością i biegłością oraz wysoką sprawnością działania (67,3\%) Niektórzy korzystają z uprawnień do samodzielnego udzielania świadczeń, przeważnie takich, jak: ocena stanu świadomości chorego z wykorzystaniem metod i klasyfikacji (75,7\%), wykonywanie badania fizykalnego (61,2\%), tlenoterapia (55,3\%), a zdecydowanie rzadziej - kierowanie na badania diagnostyczne $(20,4 \%)$.

Wnioski. Ukończenie szkolenia specjalizacyjnego w dziedzinie pielęgniarstwa opieki długoterminowej przynosi specjalistom satysfakcję i prestiż zawodowy, skutkuje większą samodzielnością zawodową a także poprawą jakości świadczonej opieki. Wysokie kwalifikacje tej kadry nie są jednak w pełni wykorzystywane.

specjaliści, dziedzina pielęgniarstwa opieki długoterminowej

\section{UTILIZATION OF THE QUALIFICATIONS OF SPECIALISTS IN LONG-TERM CARE NURSING TO IMPROVE} WHE NURSING CARE QUALIVY OF NURSING CARE OF CHRONICALIY AND TERMINALIY IL. PATIENTS

Aim of the Study. To analyse the usefulness of specialization training in the area of long-term care nursing as well as the possibilities to make use of the acquired qualifications - in the opinion of the specialists in this area.

Material and Methodology. The questionnaire survey was conducted among 162 specialists in long-term care nursing.

Results. The majority of respondents considered the specialization training as useful (91.4\%) and meeting their expectations (83.9\%). As the result of obtained specialization, they perform their work with patients better (67.9\%), demonstrate expertise and proficiency as well as high degree of efficiency (67.3\%). Some of them exercise their right to independent provision of healthcare services, predominantly the assessment of the patient's level of consciousness with the use of methods and classifications (75.7\%), physical examination (61.2\%), oxygen therapy (55.3\%), and definitely less often - referral to diagnostic tests (20.4\%).

Conclusions. Completion of a specialization training in the area of long-term care nursing brings satisfaction and professional prestige to specialists, results in increased professional independence and improvement in the quality of provided care. However, high qualifications of this professional group are underutilized. 
Podziękowania:

Autorzy wyrażają serdeczne podziękowanie za okazaną pomoc w przeprowadzeniu badań Pani mgr Lilii Kimber-Dziwisz, Konsultant w województwie mazowieckim w dziedzinie pielęgniarstwa przewlekle chorych i niepełnosprawnych, mgr Grażynie Maciążek-Chołody i mgr Annie Gryz z Radomskiego Towarzystwa Dobroczynności, mgr Grażynie Śmiarowskiej Dyrektor Zakładu Pielęgnacyjno-Opiekuńczego w Toruniu, dr Jolancie Dziewulskiej Kierownik Zakładu Opiekuńczo-Leczniczego w Chełmie, dr Iwonie Markiewicz Dyrektor Niepublicznego Zakład Opieki Zdrowotnej I-MED w Częstochowie, dr Elżbiecie Stasiak Dyrektor Stasiak Medical Team w Lublinie, mgr Barbarze Kaczmarskiej Dyrektor Zakładu Opiekuńczo-Leczniczego im. Sue Ryder Stołecznego Centrum Opiekuńczo-Leczniczego w Warszawie.

\section{Acknowledgments:}

The authors of the study would like to thank the following people for their support in conducting research: Ms Lilia Kimber -Dziwisz, MA, Consultant in the area of nursing of chronically ill and disabled people for Mazowieckie Voivodeship, Ms Grażyna Maciążek-Chołody, MA, and Anna Gryz, MA, from the Radom Charity Society, Grażyna Śmiarowska, MA, Director of the Nursing and Care Centre in Toruń, Jolanta Dziewulska, MD, Director of the Care and Treatment Centre in Chełm, Iwona Markiewicz, MD, Director of the Non-Public Healthcare Centre I-MED in Częstochowa, Elżbieta Stasiak, MD, Director of the Stasiak Medical Team in Lublin, Barbara Kaczmarska, MA, Director of the Sue Ryder Care and Treatment Facility, the Capital City Care and Treatment Centre in Warsaw.

\section{INTRODUCTION}

Given the continuously increasing number of people suffering from chronic and terminal diseases, the assurance of the quality of provided healthcare services increasingly gains importance in the healthcare system. The important role in this area belongs to nurses with specialist knowledge and skills in long-term care nursing [1]

A specialist in nursing has specific competences, including, inter alia, preparation to solving complex care issues and providing support and professional assistance to people with chronic disease and their families (or caregivers) using care and nursing services provided in institutional and non-institutional form [2]. A nurse specialist has the possibility to exercise rights to provide strictly defined healthcare services without doctor's referral [3].

According to the data of Centrum Kształcenia Podyplomowego Pielęgniarek i Położnych [Centre for Postgraduate Education of Nurses and Midwives] (CKPPiP Register of Specialists as of 22 May 2015), 1,865 specialists in long-term care nursing were registered nationwide.

The existing regulations and functioning system of postgraduate education establish formal opportunities for the utilization of the competences of highly qualified nurses with the aim of improving the quality of provided healthcare services.

\section{AIM OF THE STUDY}

The study evaluates the usefulness of specialization training in the area of long-term care nursing. Moreover, the practical possibilities of utilizing the highly specialized skills of this group of nurses were examined.

\section{DATA AND METHODS}

The questionnaire survey was conducted among 62 specialists in long-term care nursing, including the specialists from the following voivodeships: Mazowieckie (40 persons), Śląskie (21), Lubelskie (54) and KujawskoPomorskie (47). The survey was conducted throughout
December 2014 to April 2015. For the purpose of data collection the study used the author's questionnaire, previously verified in the pilot study. Statistical analyses were conducted using SPSS Statistics 22.0 software. To compare the distributions of nominal variables derived from two or more groups Pearson $\chi 2$ test was used. The strength of the relationship between two interval variables was measured using Pearson correlation coefficient.

\section{RESULTS}

The population of the study was diverse with regard to sex (F; 158, 97.5\%; M: 4, 2.5\%) with those aged 40-50 years $(\mathrm{N}=86,53.1 \%)$ and over 50 years $(\mathrm{N}=40 ; 24.7 \%)$ represented in the highest numbers. Most respondents were employed in residential long-term care facilities $(\mathrm{N}=78$; $48 \%$ ), followed by those employed in home-based longterm nursing care facilities $(\mathrm{N}=53 ; 32.7 \%)$ (Tab. 1). The average duration of employment of respondents was 23 years with the average duration of employment in longterm care of 10 years. 82 study participants completed the specialization in the years 2004-2011, and 80 - in the years 2012-2015.

\section{Tab. 1. Respondents by workplace}

\begin{tabular}{|l|c|c|}
\hline \multicolumn{1}{|c|}{\begin{tabular}{c}
\multicolumn{1}{|c|}{ Workplace } \\
residential long-term care facilities
\end{tabular}} & $\mathrm{N}$ & $\%$ \\
\hline $\begin{array}{l}\text { Care and treatment facility } \\
\text { [Zakład opiekuńczo-leczniczy - ZOL] }\end{array}$ & 34 & $21 \%$ \\
\hline $\begin{array}{l}\text { Nursing and care facility } \\
\text { [Zakład pielęgnacyjno-opiekuńczy - ZP0] }\end{array}$ & 31 & $19.1 \%$ \\
\hline $\begin{array}{l}\text { Care and treatment facility for mechanically ventilated patients } \\
\text { [Zakład opiekuńczo-leczniczy dla wentylowanych mechanicznie } \\
\text { - ZOLWM] }\end{array}$ & 13 & $8 \%$ \\
\hline $\begin{array}{l}\text { Home-based long-term nursing care } \\
\text { [Pielęgniarska opieka długoterminowa domowa - P0DD] }\end{array}$ & 53 & $32.7 \%$ \\
\hline $\begin{array}{l}\text { Chronic disease ward } \\
\text { [0ddział dla przewlekle chorych - OPCH] }\end{array}$ & 31 & $19.1 \%$ \\
\hline Total & 162 & $100 \%$ \\
\hline
\end{tabular}


In the opinion of the majority of study participants, the specialization was necessary $(\mathrm{N}=148,91.4 \%)$. The response reading "the specialization was not necessary, but it is good that it took place" was selected less often $(\mathrm{N}=11 ; 6.8 \%)$. The most important reasons for starting specialization training were the acquisition of professional experience (mean rank $1.4 ; \mathrm{N}=58$ ) and of the rights to provide specified healthcare services independently (mean rank 1.8; $\mathrm{N}=62$ ) (Tab. 2). The majority of study participants stated that their expectations regarding specialization had been met $(\mathrm{N}=136,83.9 \%)$, and the number of hours of provided training was sufficient $(\mathrm{N}=132,81.5 \%)$.

Tab. 2. Specialists' expectations with regard to specialization training in long-term care nursing

\begin{tabular}{|l|c|c|c|c|c|}
\hline \multicolumn{1}{|c|}{ Responses } & $\begin{array}{c}\text { Mean } \\
\text { rank }^{*}\end{array}$ & $\begin{array}{c}\mathrm{N} \\
\% \text { of } \\
\text { indications } \\
\text { in total }\end{array}$ & $\begin{array}{c}\text { Rank 1 } \\
\mathrm{N} \%\end{array}$ & $\begin{array}{c}\text { Rank 2 } \\
\mathrm{N} \%\end{array}$ & $\begin{array}{c}\text { Rank 3 } \\
\mathrm{N} \%\end{array}$ \\
\hline $\begin{array}{l}\text { Acquisition of professional } \\
\text { experience }\end{array}$ & 1.4 & $\begin{array}{c}54 \\
52.4 \%\end{array}$ & $\begin{array}{c}38 \\
36.9 \%\end{array}$ & $\begin{array}{c}9 \\
8.7 \%\end{array}$ & $\begin{array}{c}7 \\
6.8 \%\end{array}$ \\
\hline $\begin{array}{l}\text { Gaining rights to independent } \\
\text { provision of healthcare services }\end{array}$ & 1.8 & 62 & 26 & 21 & 12 \\
\hline $\begin{array}{l}\text { Learning the rules of managing } \\
\text { and nursing patients with } \\
\text { chronic and terminal diseases }\end{array}$ & 1.9 & $\begin{array}{c}63 \% \\
21.2 \%\end{array}$ & $\begin{array}{c}25.2 \% \\
23.3 \%\end{array}$ & $\begin{array}{c}20.4 \% \\
19.4 \%\end{array}$ & $\begin{array}{c}11.7 \% \\
18.5 \%\end{array}$ \\
\hline
\end{tabular}

*question with ranking by importance where 1 meant the most important choice, while 2 and 3 less important choices

In the opinion of the majority of study participants, completion of the specialization training ensures professional prestige $(\mathrm{N}=90 ; 55.6 \%)$ and respect of colleagues $(\mathrm{N}=28 ; 17.3 \%)$. For some respondents, it is a formal requirement related to keeping their job $(\mathrm{N}=37 ; 22.8 \%)$, and according to 31 respondents $(\mathrm{N}=16.8 \%)$ it changes nothing in their professional life.

The respondents, when asked for the impact of completed specialization on performed professional tasks, marked primarily the better quality of their own work $(\mathrm{N}=110 ; 67.9 \%)$, broader expertise, proficiency in performing related activities and high efficiency $(\mathrm{N}=109$, $67.3 \%)$ and quick decision-making $(\mathrm{N}=73 ; 45.1 \%)$. They also stressed their involvement in the provision of training to others (nurses, caregivers $\mathrm{N}=20 ; 12.3$ ), development of standards and procedures of nursing care $(\mathrm{N}=19 ; 11.7 \%)$, and coordination of nursing work $(\mathrm{N}=17,10.5 \%)$. Broader expertise and proficiency in performing nursing activities was indicated by the oldest nurses, aged over 50 years and aged 40-50 years - statistical significance: $p=0.039$ and those with the duration of employment over $21: \mathrm{p}=0.013$. Nurses with secondary education most often indicated the involvement in the development of standards and procedures (statistical significance $\mathrm{p}<0.0005$ ), nursing team leadership ( $\mathrm{p}=0.024)$ and training and teaching $(\mathrm{p}=0.001)$.

The majority of study participants stated that they exercised their right to provide specialist services individually in accordance with applicable regulations, with the exception of the right to refer to diagnostic tests (Tab. 3). According to the respondents, the decisions in this field fall within the competencies of other specialists (physi- cians), or there is no possibility to perform diagnostic tests based on the referral issued by a nurse in their workplace.

Tab. 3. Exercising rights to independent provision of certain healthcare services by specialists in long-term care nursing

\begin{tabular}{|c|c|c|c|c|}
\hline \multirow[b]{2}{*}{ Lp. } & \multirow[b]{2}{*}{ Healthcare service } & \multicolumn{3}{|c|}{ Responses } \\
\hline & & $\begin{array}{c}\text { I } \\
\text { exercise } \\
\text { such } \\
\text { rights }\end{array}$ & $\begin{array}{c}\text { I will } \\
\text { exercise } \\
\text { such } \\
\text { rights } \\
\text { in the } \\
\text { nearest } \\
\text { future }\end{array}$ & $\begin{array}{c}\text { I do not } \\
\text { exercise } \\
\text { such } \\
\text { rights }\end{array}$ \\
\hline \multicolumn{5}{|c|}{ Healthcare services requiring the completion of specialization } \\
\hline 1. & Physical examination & $\begin{array}{c}63 \\
61.2 \% \\
\end{array}$ & $\begin{array}{c}11 \\
10.7 \% \\
\end{array}$ & $\begin{array}{c}18 \\
17.5 \% \\
\end{array}$ \\
\hline 2. & $\begin{array}{l}\text { Assessment of the patient's level of } \\
\text { consciousness with the use of methods and } \\
\text { classifications }\end{array}$ & $\begin{array}{c}78 \\
75.7 \%\end{array}$ & $\begin{array}{c}8 \\
7.8 \%\end{array}$ & $\begin{array}{c}6 \\
5.8 \%\end{array}$ \\
\hline 3. & Oxygen therapy & $\begin{array}{c}57 \\
55.3 \%\end{array}$ & $\begin{array}{c}11 \\
10.7 \%\end{array}$ & $\begin{array}{c}22 \\
21.4 \%\end{array}$ \\
\hline 4. & $\begin{array}{l}\text { Referral to diagnostic tests or material } \\
\text { collection for testing }\end{array}$ & $\begin{array}{c}21 \\
20.4 \% \\
\end{array}$ & $\begin{array}{c}9 \\
8.7 \% \\
\end{array}$ & $\begin{array}{c}48 \\
46.6 \% \\
\end{array}$ \\
\hline \multicolumn{5}{|c|}{ Healthcare services requiring the completion of specialization courses } \\
\hline 5. & $\begin{array}{l}\text { Selection of the methods of wound and } \\
\text { pressure ulcers dressing }\end{array}$ & $\begin{array}{c}87 \\
84.5 \%\end{array}$ & $\begin{array}{c}5 \\
4.9 \% \\
\end{array}$ & $\begin{array}{c}5 \\
4.9 \%\end{array}$ \\
\hline 6. & $\begin{array}{l}\text { Provision of instructions in the scope of } \\
\text { bladder training in urinary incontinence } \\
\text { patients }\end{array}$ & $\begin{array}{c}47 \\
45.6 \%\end{array}$ & $\begin{array}{c}8 \\
7.8 \%\end{array}$ & $\begin{array}{c}22 \\
21.4 \%\end{array}$ \\
\hline 7. & $\begin{array}{l}\text { Provision of instructions in the scope of stump } \\
\text { conditioning after limb amputation }\end{array}$ & $\begin{array}{c}46 \\
44.7 \%\end{array}$ & $\begin{array}{c}6 \\
5.8 \% \\
\end{array}$ & $\begin{array}{c}25 \\
24.3 \%\end{array}$ \\
\hline
\end{tabular}

In the nursing and care facilities, nurses provided oxygen therapy more often than other specialists $(87.1 \%$ of those working in nursing and care facilities, statistically significant differences $\mathrm{p}=0.017$ ). Nurses of the homebased long-term care more often performed the assessment of the patient's level of consciousness $(90.6 \%$ of respondents in this group; statistical significance $\mathrm{p}=0,033$ ) and managed dressings of wounds and pressure ulcers (96.2\%; statistical significance $\mathrm{p}=0.049$ ).

In answers to the open question in the end part of the questionnaire, the respondents indicated practical and personal benefits from the completion of specialization training, including the following: improvement of qualifications ( $\mathrm{N}=56 ; 30.43 \%)$, expanding current knowledge and skills $(\mathrm{N}=31 ; 16.85 \%)$ and better care for the patient $(\mathrm{N}=19 ; 10.33 \%)$. Furthermore, the respondents indicated the salary increase $(\mathrm{N}=30,16.95 \%)$, personal satisfaction $(\mathrm{N}=27,15.25 \%)$ and professional independence $(\mathrm{N}=22$, $12.43 \%)$. The professional independence was more emphasised by the nurses of home-based long-term care (92.5\%; statistical significance $\mathrm{p}=0,008)$ and those with the duration of employment over 21 years $(78.3 \%, \mathrm{p}=0.001)$.

In addition, the respondents perceived certain systemrelated benefits of acquiring specialist qualifications, including the following: new professional opportunities of the professional group of nurses $(\mathrm{N}=22,11.96 \%)$, higher quality of the long-term care $(\mathrm{N}=19 ; 10.33 \%)$, better access to healthcare services $(\mathrm{N}=10,5.43 \%)$ and the prestige of the profession $(9 ; 4.89 \%)$. 


\section{DISCUSSION}

New, specialist competences in the area of long-term care nursing are closely connected with broader professional rights, possibility to take independent decisions and actions. They should result in better and more durable cooperation with the subject of care and the nursing and interdisciplinary team [4]. It is worth stressing that typically the involvement in issues related to the quality of work in the healthcare sector has positive impact on the increase in the general satisfaction from this work [5] In building personal job satisfaction in addition to incentives including salary increase, promotion, recognition, the important role is played by the value of work perceived by employees, including sense of responsibility, satisfaction with achievements, with much broader dimensions and more durable effects [6].

In the studies conducted in 2011 by Chmielewska among 55 nurses in the Voivodeship Specialist Hospital in Legnica, the study participants most often indicated the interest in the specialization training in the area of long-term, conservative and geriatric care, perceiving the opportunities for gaining more independence and professionalism [7]. Nevertheless, improved qualifications are not necessarily connected with enhanced professional prospects like promotion or pay rise. This fact was stressed by the nurses from the $10^{\text {th }}$ Military Clinical Hospital in
Bydgoszcz who participated in the survey research conducted in 2012 by Głowacka, Haor, Ślusarz et al. [8].

The conducted studies demonstrate that the completion of the specialization training in the area of long-term care nursing is associated with the satisfaction and professional prestige of the specialists. It satisfies internal motivation, but its financial benefits are less pronounced. The high qualifications of this staff are underutilised. This situation could be improved with more open attitude of employers and enhanced incentive measures towards the staff.

\section{CONCLUSIONS}

The majority of specialists in long-term care nursing who participated in the study stress the usefulness of the completed specialization training, especially as regards the acquisition of professional experience and rights to independent provision of specified healthcare services. Few specialists could see the positive impact of improved competences of nurses on the improvement in the quality and accessibility of the long-term care. Despite new professional opportunities created by the completed specialization, high qualifications of the nursing staff are underutilized in workplaces.

\section{Znaczenie szkolenia specjalizacyjnego i możliwości wykorzystania kwalifikacji specjalistów w dziedzinie pielęgniarstwa opieki długoterminowej w zakresie poprawy jakości opieki pielęgniarskiej nad przewlekle i nieuleczalnie chorymi}

\section{WPROWADZENIE}

Wobec nieustannie wzrastającej liczby osób przewlekle chorych i niepełnosprawnych w systemie ochrony zdrowia coraz większego znaczenia nabiera zapewnienie jakości udzielanych świadczeń zdrowotnych. Ważną rolę pełni tu kadra, która uzyskała specjalistyczną wiedzę i umiejętności w dziedzinie pielęgniarstwa opieki długoterminowej [1]. Specjalistę w dziedzinie pielęgniarstwa cechują szczególne kompetencje m.in. przygotowanie do rozwiązywania złożonych problemów pielęgnacyjnych oraz udzielania wsparcia i profesjonalnej pomocy osobom przewlekle chorym i ich rodzinom (lub opiekunom), korzystającym ze świadczeń pielęgnacyjnych i opiekuńczych, realizowanych w formie instytucjonalnej oraz pozainstytucjonalnej [2]. Pielęgniarka legitymująca się tytułem specjalisty ma możliwość skorzystania z uprawnień do udzielania ściśle określonych świadczeń zdrowotnych, bez zlecenia lekarskiego [3]. Według danych Centrum Kształcenia Podyplomowego Pielęgniarek i Położnych (Rejestr specjalistów CKPPiP. Stan na dzień 22 maja 2015 r.) w całym kraju zarejestrowano 1865 specjalistów w dziedzinie pielęgniarstwa opieki długoterminowej.

Istniejące regulacje prawne oraz funkcjonujący system kształcenia podyplomowego tworzą formalne możliwości wykorzystania kompetencji wysoko wykwalifikowanych pielęgniarek w kierunku poprawy jakości świadczonej opieki zdrowotnej.

\section{CEL PRACY}

W pracy podjęto próbę oceny przydatności szkolenia specjalizacyjnego w dziedzinie pielęgniarstwa opieki długoterminowej. Zbadano również praktyczne możliwości wykorzystania wysoko specjalistycznych kwalifikacji tej grupy pielęgniarek. 
Ewa Kądalska, Halina Żmuda-Trzebiatowska, Katarzyna Pawłowska

\section{MATERIAŁ I METODY}

Badaniami ankietowymi objęto 162 specjalistów w dziedzinie pielęgniarstwa opieki długoterminowej, w tym z województw: mazowieckiego (40 osób), śląskiego (21), lubelskiego (54) oraz kujawsko-pomorskiego (47). Badania przeprowadzono w okresie od grudnia 2014 r. do kwietnia 2015 r. Posłużono się autorskim kwestionariuszem, skonstruowanym dla potrzeb badania, uprzednio zweryfikowanym w badaniu pilotażowym. Do analiz statystycznych wykorzystano program SPSS Statistics 22.0. Celem porównania rozkładów zmiennych nominalnych, pochodzących z dwóch lub większej liczby grup badanych zastosowano test $\chi^{2}$ Pearsona. Siłę związku dwóch zmiennych przedziałowych oceniano przy zastosowaniu współczynnika korelacji Pearsona.

\section{WYNIKI}

Grupa badana była zróżnicowana pod względem płci (K; 158, 97,5\%; M: 4, 2,5\%) i najliczniej reprezentowana przez osoby w wieku $40-50$ lat $(\mathrm{N}=86,53,1 \%)$ oraz powyżej 50 -ciu lat $(\mathrm{N}=40 ; 24,7 \%)$. Najwięcej badanych było zatrudnionych w zakładach stacjonarnej opieki długoterminowej ( $\mathrm{N}=78 ; 48 \%)$, a następnie - w zakładach pielęgniarskiej domowej opieki długoterminowej $(\mathrm{N}=53$; $32,7 \%$ ) (Tab. 1). Średni staż pracy ankietowanych wynosił 23 lata; w opiece długoterminowej natomiast - 10 lat. Specjalizację w latach 2004-2011 ukończyły 82 osoby uczestniczące w badaniach, a w latach 2012-2015 - 80 osób.

Tab. 1. Respondenci według miejsca pracy

\begin{tabular}{|l|c|c|}
\hline \multicolumn{1}{|c|}{ Miejsce pracy } & N & $\%$ \\
\hline Zakład opiekuńczo-leczniczy - ZOL & 34 & $21 \%$ \\
\hline Zakład pielęgnacyjno-opiekuńczy - ZPO & 31 & $19,1 \%$ \\
\hline $\begin{array}{l}\text { Zakład opiekuńczo-leczniczy dla wentylowanych mechanicznie } \\
\text {-ZOLWM }\end{array}$ & 13 & $8 \%$ \\
\hline Pielęgniarska opieka długoterminowa domowa - PODD & 53 & $32,7 \%$ \\
\hline Oddział dla przewlekle chorych - OPCH & 31 & $19,1 \%$ \\
\hline Razem & 162 & $100 \%$ \\
\hline
\end{tabular}

Zdaniem większości badanych specjalizacja była potrzebna ( $\mathrm{N}=148,91,4 \%)$. Rzadziej zaznaczano odpowiedź w brzmieniu: „specjalizacja nie była konieczna ale dobrze, że się odbyła" ( $\mathrm{N}=11 ; 6,8 \%)$. Najważniejsze przesłanki, którymi kierowali się badani podejmując specjalizację to zdobycie doświadczenia zawodowego (średnia ranga 1,$4 ; \mathrm{N}=58$ ) oraz zdobycie uprawnień do samodzielnego wykonywania określonych świadczeń zdrowotnych (średnia ranga 1,8; N=62) (Tab. 2). Uczestnicy badań w większości stwierdzili, że ich oczekiwania wobec specjalizacji zostały spełnione $(\mathrm{N}=136,83,9 \%)$ a liczba godzin zrealizowanych zajęć była wystarczająca (N=132, 81,5\%).

Według większości badanych ukończenie specjalizacji zapewnia im prestiż zawodowy $(\mathrm{N}=90 ; 55,6 \%)$ oraz szacunek współpracowników $(\mathrm{N}=28 ; 17,3 \%)$. Dla niektórych respondentów - to wymóg formalny, związany z utrzymaniem miejsca pracy $(\mathrm{N}=37 ; 22,8 \%)$ a według 31 ankieto- wanych $(16,8 \%)$ - nic to nie zmienia w ich życiu zawodowym.

Tab. 2. Własne oczekiwania specjalistów wobec szkolenia specjalizacyjnego w dziedzinie pielęgniarstwa opieki długoterminowej

\begin{tabular}{|l|c|c|c|c|c|}
\hline \multicolumn{1}{|c|}{ Odpowiedzi } & $\begin{array}{c}\text { Średnia } \\
\text { ranga }\end{array}$ & $\begin{array}{c}\mathrm{N} \\
\text { Procent } \\
\text { wskazań } \\
\text { łącznie }\end{array}$ & $\begin{array}{c}\text { Ranga 1 } \\
\text { N } \\
\text { Procent }\end{array}$ & $\begin{array}{c}\text { Ranga 2 } \\
\text { Procent }\end{array}$ & $\begin{array}{c}\text { Ranga 3 } \\
\text { Procent }\end{array}$ \\
\hline $\begin{array}{l}\text { Zdobycie doświadczenia } \\
\text { zawodowego }\end{array}$ & 1,4 & $\begin{array}{c}54 \\
52,4 \%\end{array}$ & $\begin{array}{c}38 \\
36,9 \%\end{array}$ & $\begin{array}{c}9 \\
8,7 \%\end{array}$ & $\begin{array}{c}7 \\
6,8 \%\end{array}$ \\
\hline $\begin{array}{l}\text { Zdobycie uprawnień do } \\
\text { samodzielnego wykonywania } \\
\text { Świadczeń zdrowotnych }\end{array}$ & 1,8 & 62 & 26 & 21 & 12 \\
\hline $\begin{array}{l}\text { Nauczenie się zasad } \\
\text { postępowania wobec } \\
\text { przewlekle i nieuleczalnie } \\
\text { chorego oraz pielęgnacji }\end{array}$ & 1,9 & $\begin{array}{c}63 \% \\
25,2 \%\end{array}$ & $\begin{array}{c}24,4 \% \\
23,3 \%\end{array}$ & $\begin{array}{c}20 \\
19,4 \%\end{array}$ & $\begin{array}{c}19,7 \% \\
18,5 \%\end{array}$ \\
\hline
\end{tabular}

* pytanie z rangowaniem według ważności, gdzie cyfra 1 oznaczała wybór najważniejszy a 2 i 3 mniej ważny;

Respondenci zapytani o wpływ ukończonej specjalizacji na realizowane przez nich zadania zawodowe, zaznaczali przeważnie lepszą jakość własnej pracy $(\mathrm{N}=110$; 67,9\%), większą fachowość, biegłość w wykonywaniu czynności i wysoką sprawność $(\mathrm{N}=109 ; 67,3 \%)$ a także szybkość podejmowania decyzji ( $\mathrm{N}=73 ; 45,1 \%)$. Podkreślali również własne zaangażowanie w szkolenie innych (pielęgniarek, opiekunów $\mathrm{N}=20 ; 12,3$ ), opracowywanie standardów i procedur postępowania pielęgniarskiego $(\mathrm{N}=19 ; 11,7 \%)$, jak również koordynację pracy pielęgniarskiej $(\mathrm{N}=17 ; 10,5 \%)$. Większą fachowość i biegłość w wykonywaniu czynności wskazywały pielęgniarki najstarsze pow. 50 r.ż. i w wieku 40-50 lat - istotność statystyczna: $\mathrm{p}=0,039$ oraz legitymujące się stażem pracy pow. 21 lat: $p=0,013$. Pielęgniarki $z$ wykształceniem średnim przeważnie podawały zaangażowanie w opracowywanie standardów i procedur (istotność statystyczna $\mathrm{p}<0,0005)$, przewodzenie $\mathrm{w}$ zespole pielęgniarskim $(\mathrm{p}=0,024)$ oraz szkolenie i nauczanie innych $(\mathrm{p}=0,001)$.

Większość badanych podała, że korzysta z przysługujących im uprawnień do samodzielnego wykonywania specjalistycznych świadczeń, zgodnie z obowiązującymi regulacjami prawnymi, za wyjątkiem możliwości kierowania na badania diagnostyczne (Tab. 3).Według ankietowanych decyzje w tej kwestii mieszczą się w kompetencjach innych specjalistów (lekarzy) lub nie ma możliwości realizacji zleceń wykonania badań diagnostycznych wystawionych przez pielęgniarkę w ich miejscach pracy.

W zakładach pielęgnacyjno-opiekuńczych pielęgniarki częściej niż inne specjalistki stosowały tlenoterapię (87,1\% pracujących w ZPO, różnice istotne statystycznie $\mathrm{p}=0,017)$. Pielęgniarki opieki długoterminowej domowej częściej prowadziły ocenę stanu świadomości chorego (90,6\% badanych z tej grupy; istotność statystyczna $\mathrm{p}=0,033$ ) a także wykonywały opatrywanie ran i odleżyn $(96,2 \%$; istotność statystyczna $\mathrm{p}=0,049)$.

W pytaniu otwartym zamieszczonym w końcowej części kwestionariusza ankiety respondenci wskazywali praktyczne i osobiste korzyści z ukończenia szkolenia specjalizacyjnego, w tym: podniesienie kwalifikacji $(\mathrm{N}=56 ; 30,43 \%)$, poszerzenie dotychczasowej wiedzy 
Tab. 3. Wykorzystanie uprawnień do samodzielnego udzielania niektórych świadczeń przez specjalistów w dziedzinie pielęgniarstwa opieki długoterminowej

\begin{tabular}{|c|c|c|c|c|}
\hline \multirow[b]{2}{*}{ Lp. } & \multirow[b]{2}{*}{ Nazwa świadczenia } & \multicolumn{3}{|c|}{ Odpowiedzi } \\
\hline & & $\begin{array}{l}\text { Korzystam } \\
\text { z takich } \\
\text { uprawnień }\end{array}$ & $\begin{array}{c}\text { Będę } \\
\text { korzystać } \\
\text { z takich } \\
\text { uprawnień } \\
\text { w najbliższej } \\
\text { przyszłości }\end{array}$ & $\begin{array}{l}\text { Nie } \\
\text { korzystam } \\
\text { z takich } \\
\text { uprawnień }\end{array}$ \\
\hline \multicolumn{5}{|c|}{ Świadczenia wymagające ukończenia specjalizacji } \\
\hline 1. & Wykonywanie badania fizykalnego & $\begin{array}{c}63 \\
61,2 \%\end{array}$ & $\begin{array}{c}11 \\
10,7 \%\end{array}$ & $\begin{array}{c}18 \\
17,5 \%\end{array}$ \\
\hline 2. & $\begin{array}{l}\text { Ocena stanu świadomości chorego } \\
\text { z wykorzystaniem metod i klasyfikacji }\end{array}$ & $\begin{array}{c}78 \\
75,7 \% \\
\end{array}$ & $\begin{array}{c}8 \\
7,8 \% \\
\end{array}$ & $\begin{array}{c}6 \\
5,8 \% \\
\end{array}$ \\
\hline 3. & Tlenoterapia & $\begin{array}{c}57 \\
55,3 \% \\
\end{array}$ & $\begin{array}{c}11 \\
10,7 \% \\
\end{array}$ & $\begin{array}{c}22 \\
21,4 \% \\
\end{array}$ \\
\hline 4. & $\begin{array}{l}\text { Kierowanie na badania diagnostyczne } \\
\text { lub pobieranie materiałów do badań }\end{array}$ & $\begin{array}{c}21 \\
20,4 \% \\
\end{array}$ & $\begin{array}{c}9 \\
8,7 \% \\
\end{array}$ & $\begin{array}{c}48 \\
46,6 \% \\
\end{array}$ \\
\hline \multicolumn{5}{|c|}{ Świadczenia wymagające ukończenia kursów specjalistycznych } \\
\hline 5. & $\begin{array}{l}\text { Dobór sposobów opatrywania ran } \\
\text { i odleżyn }\end{array}$ & $\begin{array}{c}87 \\
84,5 \% \\
\end{array}$ & $\begin{array}{c}5 \\
4,9 \% \\
\end{array}$ & $\begin{array}{c}5 \\
4,9 \% \\
\end{array}$ \\
\hline 6. & $\begin{array}{l}\text { Prowadzenie instruktażu w zakresie } \\
\text { treningu pęcherza moczowego } \\
\text { u chorych z problemem nietrzymania } \\
\text { moczu }\end{array}$ & $\begin{array}{c}47 \\
45,6 \%\end{array}$ & $\begin{array}{c}8 \\
7,8 \%\end{array}$ & $\begin{array}{c}22 \\
21,4 \%\end{array}$ \\
\hline 7. & $\begin{array}{l}\text { Prowadzenie instruktażu w zakresie } \\
\text { hartowania i kształtowania kikuta } \\
\text { kończyny amputowanej }\end{array}$ & $\begin{array}{c}46 \\
44,7 \%\end{array}$ & $\begin{array}{c}6 \\
5,8 \%\end{array}$ & $\begin{array}{c}25 \\
24,3 \%\end{array}$ \\
\hline
\end{tabular}

i umiejętności $(\mathrm{N}=31 ; 16,85 \%)$ oraz lepszą opiekę nad pacjentem $(\mathrm{N}=19 ; 10,33 \%)$. Badani wskazali również na podwyżkę wynagrodzenia $(\mathrm{N}=30 ; 16,95 \%)$, satysfakcję osobistą $(\mathrm{N}=27 ; 15,25 \%)$ i samodzielność zawodową $(\mathrm{N}=22 ; 12,43 \%)$. Samodzielność zawodowa była silniej akcentowana przez pielęgniarki opieki długoterminowej domowej (92,5\%; istotność statystyczna p=0,008) oraz osoby legitymujące się stażem pracy powyżej 21 lat $(78,3 \% ; p=0,001)$. Satysfakcję osobista silniej podkreślały pielęgniarki z oddziałów dla przewlekle chorych $(100 \%$; istotność statystyczna $\mathrm{p}=0,022$ ) oraz osoby $\mathrm{z}$ wykształceniem wyższym zawodowym (istotność statystyczna $\mathrm{p}=0,006)$.

Respondenci dostrzegali również niektóre systemowe korzyści uzyskania specjalistycznych kwalifikacji takie, jak: nowe możliwości zawodowe grupy zawodowej pielęgniarek ( $\mathrm{N}=22,11,96 \%)$, lepsza jakość opieki długoterminowej $(\mathrm{N}=19 ; 10,33 \%)$, większa dostępność świadczeń $(\mathrm{N}=10 ; 5,43 \%)$ i prestiż profesji $(9 ; 4,89 \%)$.

\section{DYSKUSJA}

Nowe, specjalistyczne kompetencje w dziedzinie pielęgniarstwa opieki długoterminowej wiążą się ściśle z szerszymi uprawnieniami zawodowymi, z możliwością podejmowania samodzielnych decyzji i działań. Powinny one skutkować lepszą i trwalszą współpracą z podmiotem opieki, z zespołem pielęgniarskim oraz interdyscyplinarnym [4].

Wzrostowi ogólnej satysfakcji z pracy w sektorze ochrony zdrowia sprzyja zazwyczaj zaangażowanie w sprawy związane z zapewnieniem jej jakości [5].
W budowaniu osobistej satysfakcji z pracy, oprócz czynników motywacyjnych, takich, jak: wzrost wynagrodzenia, awans, uznanie, istotną rolę odgrywa wartość pracy odczuwana przez pracownika, w tym poczucie odpowiedzialności, satysfakcji z osiągnięć, o znacznie szerszym wymiarze i trwalszych efektach [6].

W badaniach przeprowadzonych przez Chmielewska w 2011 roku wśród 55 pielęgniarek w Wojewódzkim Szpitalu Specjalistycznym w Legnicy najchętniej wskazywano na zainteresowanie podjęciem specjalizacji w dziedzinie opieki długoterminowej, zachowawczej i geriatrycznej, dostrzegając szanse uzyskania większej samodzielności i profesjonalizmu [7]. Jednak podniesienie kwalifikacji nie zawsze otwiera lepsze perspektywy zawodowe takie, jak awans lub podwyżka. Ten fakt podkreślały pielęgniarki z 10. Wojskowego Szpitala Klinicznego w Bydgoszczy uczestniczące w 2012 r. w badaniu sondażowym autorstwa Głowackiej, Haor, Ślusarz i innych współautorów [8].

Z przeprowadzonych badań wynika, że ukończenie szkolenia specjalizacyjnego $\mathrm{w}$ dziedzinie pielęgniarstwa opieki długoterminowej przynosi specjalistom satysfakcję i prestiż zawodowy. Zaspokaja motywację wewnętrzną ale w mniejszym stopniu przynosi korzyści finansowe. Wysokie kwalifikacje tej kadry nie są jednak w pełni wykorzystywane. Skuteczne mogłoby się tu okazać większe otwarcie pracodawców na nowe możliwości i wzmocnione oddziaływania motywacyjne.

\section{WNIOSKI}

Większość badanych specjalistów w dziedzinie pielęgniarstwa opieki długoterminowej podkreśla przydatność ukończonego szkolenia specjalizacyjnego, głównie w zakresie zdobycia doświadczenia zawodowego a także uprawnień do samodzielnego wykonywania określonych świadczeń zdrowotnych. Tylko nieliczni specjaliści potrafią dostrzec pozytywny wpływ wyższych kompetencji pielęgniarek na poprawę jakości i dostępności opieki długoterminowej. Pomimo nowych możliwości zawodowych jakie stwarza ukończona specjalizacja wysokie kwalifikacje kadry nie są w pełni wykorzystywane w zakładach pracy.

\section{PIŚMIENNICTWO/REFERENCES}

1. Ustawa z dnia 15 lipca 2011r. o zawodach pielęgniarki i położnej (art. 67 ust.1. Dz.U. Nr 174, poz. 1039 z późn. zm.).

2. Rozporządzenie Ministra Zdrowia z dnia 22 listopada 2013r. w sprawie świadczeń gwarantowanych z zakresu świadczeń pielęgnacyjnych i opiekuńczych w ramach opieki długoterminowej (Dz. U. z 2013 r. poz.1480).

3. Rozporządzenie Ministra Zdrowia z dnia 7 listopada 2007r. w sprawie rodzaju i zakresu świadczeń zapobiegawczych, diagnostycznych, leczniczych i rehabilitacyjnych udzielanych przez pielęgniarkę albo położną samodzielnie, bez zlecenia lekarskiego (Dz. U. Nr 210, poz. 1540).

4. Bielawska J. Kompetencje zawodowe pielęgniarki. Legnica: Zeszyty Naukowe Państwowej Wyższej Szkoły Zawodowej im. Witelona. 2012;8: 5-15.

5. Opolski K, Dykowska G, Możdżonek M. Zarządzanie przez jakość w usługach zdrowotnych. Warszawa: Wydawnictwo CeDeWu; 2005.

6. Armstrong M. Zarządzanie ludźmi. Praktyczny przewodnik dla menedżerów liniowych. Poznań: Dom Wydawniczy Rebis; 2007.

7. Chmielewska E. Wpływ czynników motywujących na kształcenie podyplomowe pielęgniarek w Wojewódzkim Szpitalu Specjalistycznym w Legnicy. Legnica: Zeszyty Naukowe Państwowej Wyższej Szkoły Zawodowej im. Witelona. 2012;8:19-32.

8. Głowacka, M., Haor B, Ślusarz R, i wsp. Zainteresowanie pielęgniarek kształceniem ustawicznym. Problemy Pielęgniarstwa 2014; 22(2):271-275. 
Praca przyjęta do druku/Manuscript received: 01.10.2015

Praca zaakceptowana do druku/Manuscript accepted: 18.11.2015

Tłumaczenie/Translation: Monika Hankiewicz - LIDEX Sp. z o.o. Centrum Tłumaczeń i Obsługi Konferencji w Warszawie 